THE RING 33, 1-2 (2011) DOI 10.2478/v10050-011-0006-4

\title{
BURULLUS RINGING STATION (N EGYPT) - RINGING RESULTS AND SEASONAL BIRD MIGRATION DYNAMICS IN 2005-2007
}

\author{
Grzegorz Zaniewicz and Jacek Chruściel
}

\begin{abstract}
Zaniewicz G., Chruściel J. 2011. Burullus ringing station (N Egypt) - ringing results and seasonal bird migration dynamics in 2005-2007. Ring 33, 1-2: 77-87.

Burullus Ringing Station is one of the several stations belonging to the SEEN organization (SE European Bird Migration Network). This station is situated close to the border of Burullus Protected Area in the northern part of Egypt and it started work in 2005. Data were collected during two spring and three autumn seasons. Birds were caught in mist-nets, which were placed mainly in reedbeds. Over 12 thousands of birds from 74 species were caught and ringed during five migratory seasons. Many of them were also tested for directional preferences in Busse's cage.
\end{abstract}

G. Zaniewicz, J. Chruściel, Bird Migration Research Station, University of Gdańsk, Al. Marszałka Piłsudskiego 46, PL-81-378 Gdynia, Poland, E-mail: zidia@wp.pl

Publication appointed to the SE European Bird Migration Network papers

Key words: ringing, migration dynamics, Burullus, northern Egypt

\section{STUDY AREA AND METHODS}

Lake Burullus $\left(31^{\circ} 31^{\prime} \mathrm{N}, 30^{\circ} 55^{\prime} \mathrm{E}\right)$ is situated north-east of the Rosetta Branch of the River Nile (Fig. 1). The reservoir is a central part of five lakes: the most western Mariut, Edku, Burullus, Manzala in the eastern delta and Bardawil in Sinai. The lakes form a kind of a chain stretched along $500 \mathrm{~km}$ of the Mediterranean coastal front passed by migratory birds during their seasonal migration (Shaltout 2010). Burullus is the second largest natural lake in Egypt. Its surface covers $570 \mathrm{~km}^{2}$ and the depth ranges from 50 to $160 \mathrm{~cm}$ (Ramdani et al. 2001). The lake is stretched for $65 \mathrm{~km}$ from east to west and has a width between 6 and $21 \mathrm{~km}$ (11 km on average).

Lake Burullus is directly connected with the Mediterranean Sea by six drains Bugaz El Burullus, located in the north-eastern corner of the lake. Except drains the rest of the lake is separated from the sea by a broad stripe of dunes, which predomi- 
nantly forms the northern shore of the reservoir. Salinity in the lake increases towards north-east as the distance to the drains decreases. Consequently, the northern shore is dominated by mudflats, salt marshes and sand dunes while the southern shore is bordered by an extensive fringe of reed-swamps (Phragmites and Typha spp.), which covers about $25 \%$ of the lake area. There are also some islands (50) with a total area of $0.7 \mathrm{~km}^{2}$.

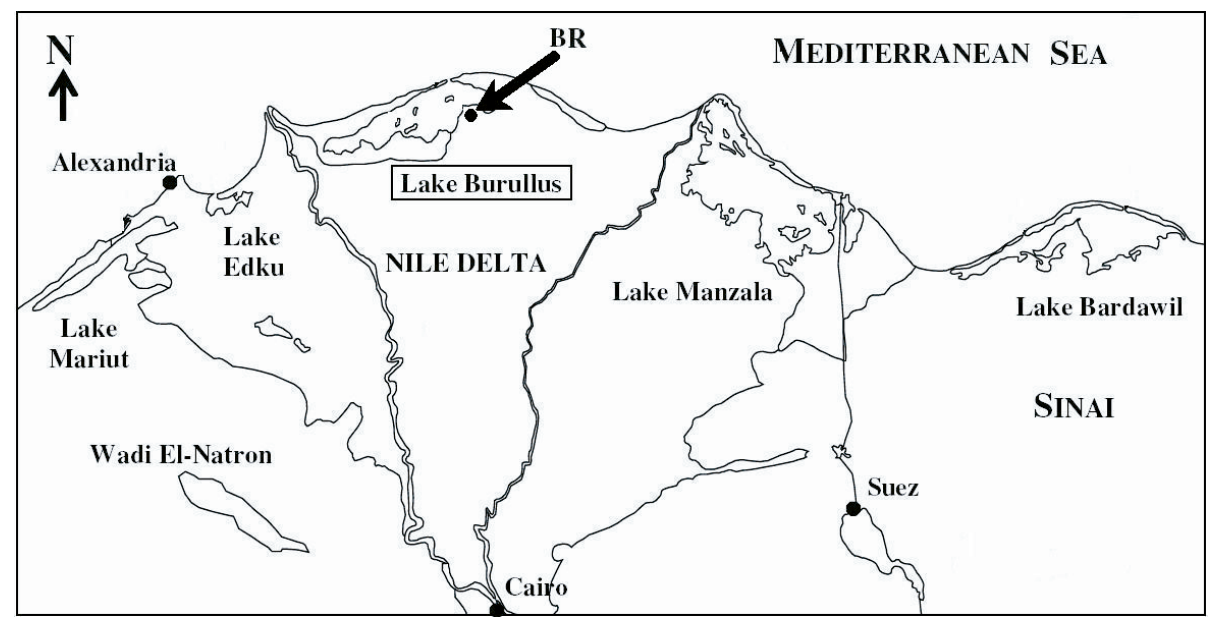

Fig. 1. Location of the ringing site (BR - Burullus Ringing Station) and five coastal lakes of Egypt

Ringing place was situated outside the Protected Area at the fish farms that stretch along the southern shore of Burullus. Nets were located mainly in the reedbeds (Plate 1).

Firstly, birds were caught in the mist-nets and subsequently their species were determined, after that they were ringed and further sexed (if possible) and aged according to plumage features and sometimes skull ossification (Busse 1984, Svensson 1992). Material collected from trapped birds includes: the level of fat deposit according to a 9 score scale (from 0 to 8 ) proposed by Busse (2000), wing and tail length, wing formula and weight to the nearest $0.1 \mathrm{~g}$. Moreover, some (particularly night) migrants were tested in Busse's cage for their directional preferences (Busse 1995, 2000).

\section{RESULTS}

Totally, during five migratory seasons (3 autumns and 2 springs) we caught 12537 individuals representing 74 bird species (Table 1, Fig. 2). In each autumn and spring season the working time at Burullus Ringing Station varied. The dates of catching in autumn were as follows: 1 Sep. -2 Nov. 2005, 28 Aug. -6 Nov. 2006 and 2 Sep. -3 Nov. 2007; in spring: 12 Mar. - 8 May 2006 and 5 Mar. - 2 May 2007. Except the first season of our activity (autumn 2005), when the most numerous species was the Kingfisher (Alcedo atthis), $N=548$, in all other seasons the Sedge Warbler (Acrocephalus schoenobaenus) was clearly dominant. 

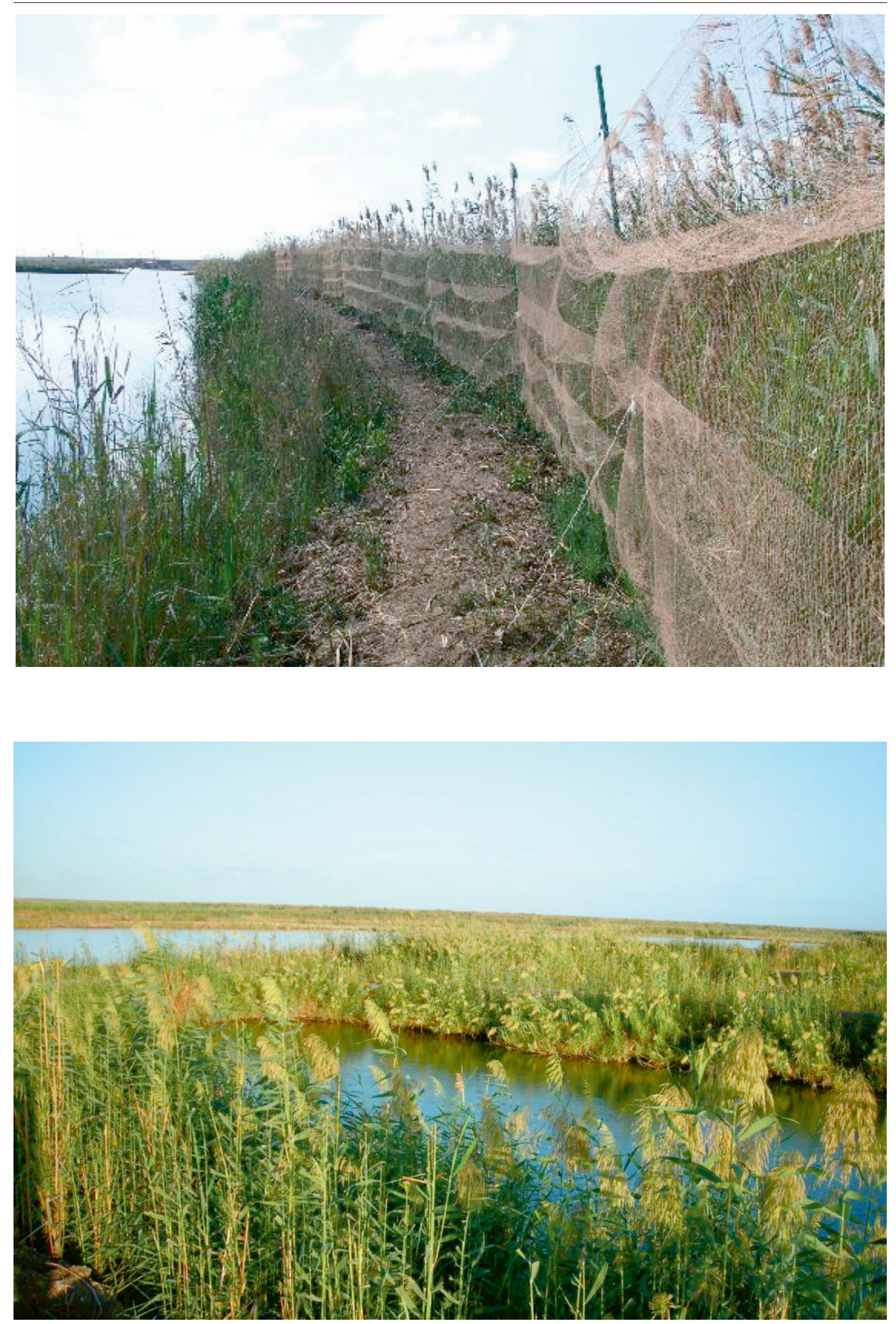

Plate 1. Available biotopes surrounding the Burullus Ringing Station (Photo by G. Zaniewicz) 
Table 1

The list of ringed birds

\begin{tabular}{|c|c|c|c|c|c|c|c|}
\hline \multirow[b]{2}{*}{ Scientific name } & \multirow{2}{*}{$\begin{array}{l}\text { Species } \\
\text { code } \\
\text { in Fig. } 2\end{array}$} & \multicolumn{3}{|c|}{ Autumn } & \multicolumn{2}{|c|}{ Spring } & \multirow[b]{2}{*}{ Total } \\
\hline & & 2005 & 2006 & 2007 & 2006 & 2007 & \\
\hline Accipiter nisus & & 0 & 0 & 0 & 0 & 1 & 1 \\
\hline Acrocephalus arundinaceus & ACR.ARU & 14 & 11 & 11 & 152 & 152 & 340 \\
\hline Acrocephalus palustris & & 2 & 0 & 3 & 0 & 0 & 5 \\
\hline Acrocephalus schoenobaenus & ACR.ENO & 442 & 582 & 375 & 909 & 1497 & 3805 \\
\hline Acrocephalus scirpaceus & ACR.IRP & 121 & 193 & 108 & 220 & 615 & 1257 \\
\hline Acrocephalus stentoreus & ACR.STE & 206 & 169 & 108 & 118 & 86 & 687 \\
\hline Actitis hypoleucos & & 0 & 1 & 0 & 1 & 0 & 2 \\
\hline Alcedo atthis & ALC.ATT & 548 & 382 & 213 & 8 & 14 & 1165 \\
\hline Anthus trivialis & & 0 & 0 & 0 & 2 & 0 & 2 \\
\hline Ardeola ralloides & & 2 & 0 & 0 & 1 & 1 & 4 \\
\hline Ayhene noctua & & 1 & 1 & 0 & 1 & 0 & 3 \\
\hline Centropus senegalensis & & 5 & 1 & 0 & 1 & 0 & 7 \\
\hline Ceryle rudis & CER.RUD & 20 & 10 & 13 & 67 & 40 & 150 \\
\hline Clamator glandarius & & 0 & 0 & 0 & 0 & 1 & 1 \\
\hline Coturnix coturnix & & 1 & 0 & 0 & 0 & 0 & 1 \\
\hline Emberiza hortulana & & 1 & 1 & 0 & 0 & 0 & 2 \\
\hline Erithacus rubecula & & 1 & 1 & 3 & 1 & 1 & 7 \\
\hline Falco tinnunculus & & 1 & 6 & 0 & 0 & 1 & 8 \\
\hline Ficedula albicolllis & & 0 & 2 & 3 & 0 & 1 & 6 \\
\hline Ficedula parva & & 1 & 1 & 0 & 0 & 0 & 2 \\
\hline Ficedula semitorquata & & 0 & 0 & 0 & 1 & 0 & 1 \\
\hline Galerida cristata & & 0 & 0 & 0 & 0 & 3 & 3 \\
\hline Gallinago gallinago & & 0 & 0 & 0 & 1 & 0 & 1 \\
\hline Gallinula chloropus & & 1 & 1 & 0 & 2 & 1 & 5 \\
\hline Garrulus glandarius & & 0 & 1 & 0 & 0 & 0 & 1 \\
\hline Glareola pratincola & & 0 & 0 & 0 & 2 & 0 & 2 \\
\hline Halcyon smyrnensis & HAL.SMY & 7 & 4 & 5 & 12 & 4 & 32 \\
\hline Hippolais icterina & & 0 & 0 & 4 & 0 & 0 & 4 \\
\hline Hirundo rustica & HIR.RUS & 344 & 365 & 166 & 21 & 17 & 913 \\
\hline Ixobrychus minutus & IXO.MIN & 101 & 43 & 31 & 24 & 14 & 213 \\
\hline Jynx torquilla & & 2 & 4 & 3 & 0 & 3 & 12 \\
\hline Lanius collurio & LAN.COL & 29 & 52 & 28 & 0 & 0 & 109 \\
\hline Lanius senator & & 2 & 0 & 0 & 0 & 0 & 2 \\
\hline Locustella fluviatilis & & 0 & 0 & 2 & 0 & 0 & 2 \\
\hline Locustella luscinioides & LOC.LUS & 13 & 9 & 5 & 8 & 9 & 44 \\
\hline Luscinia luscinia & & 1 & 14 & 6 & 0 & 1 & 22 \\
\hline Luscinia megarhynchos & & 2 & 0 & 1 & 10 & 16 & 29 \\
\hline Luscinia svecica & LUS.SVE & 76 & 83 & 36 & 60 & 92 & 347 \\
\hline Merops apiaster & & 1 & 2 & 0 & 1 & 0 & 4 \\
\hline Merops persicus & MER.PER & 23 & 21 & 16 & 3 & 6 & 69 \\
\hline Motacilla alba & & 4 & 11 & 4 & 3 & 2 & 24 \\
\hline
\end{tabular}


THE RING 33, 1-2 (2011)

\begin{tabular}{|c|c|c|c|c|c|c|c|}
\hline Motacilla citreola & & 1 & 0 & 0 & 0 & 0 & 1 \\
\hline Motacilla flava & MOT.FLA & 65 & 47 & 22 & 83 & 102 & 319 \\
\hline Muscicapa striata & & 11 & 10 & 10 & 0 & 0 & 31 \\
\hline Oenanthe hispanica & & 0 & 1 & 1 & 0 & 0 & 2 \\
\hline Oenanthe isabellina & & 0 & 0 & 0 & 0 & 1 & 1 \\
\hline Oenanthe oenanthe & & 2 & 2 & 0 & 2 & 1 & 7 \\
\hline Oriolus oriolus & & 1 & 0 & 0 & 0 & 0 & 1 \\
\hline Otus scops & & 0 & 0 & 0 & 0 & 1 & 1 \\
\hline Passer domesticus & PAS.DOM & 83 & 123 & 31 & 284 & 24 & 545 \\
\hline Passer hispaniolensis & & 11 & 0 & 0 & 6 & 3 & 20 \\
\hline Phoenicurus phoenicurus & & 2 & 2 & 2 & 1 & 1 & 8 \\
\hline Phylloscopus collybita & PHY.COL & 93 & 74 & 26 & 189 & 149 & 531 \\
\hline Phylloscopus sibilatrix & & 2 & 2 & 4 & 0 & 1 & 9 \\
\hline Phylloscopus trochilus & PHY.LUS & 499 & 357 & 234 & 1 & 2 & 1093 \\
\hline Ploceus manyar & PLO.MAN & 34 & 30 & 12 & 28 & 2 & 106 \\
\hline Porzana parva & & 0 & 1 & 0 & 0 & 0 & 1 \\
\hline Porzana porzana & & 3 & 0 & 0 & 0 & 2 & 5 \\
\hline Prinia gracilis & & 9 & 6 & 6 & 6 & 3 & 30 \\
\hline Pycnonotus barbatus & & 0 & 0 & 0 & 1 & 0 & 1 \\
\hline Riparia riparia & RIP.RIP & 160 & 54 & 73 & 37 & 40 & 364 \\
\hline Saxicola rubetra & SAX.TRA & 18 & 15 & 20 & 0 & 5 & 58 \\
\hline Saxicola torquata & & 4 & 0 & 0 & 2 & 0 & 6 \\
\hline Streptopelia senegalensis & & 1 & 0 & 0 & 0 & 3 & 4 \\
\hline Streptopelia turtur & & 0 & 1 & 1 & 1 & 0 & 3 \\
\hline Sylvia atricapilla & & 2 & 2 & 0 & 0 & 4 & 8 \\
\hline Sylvia borin & & 1 & 7 & 4 & 1 & 2 & 15 \\
\hline Sylvia cantillans & & 0 & 0 & 0 & 1 & 0 & 1 \\
\hline Sylvia communis & & 2 & 9 & 13 & 1 & 2 & 27 \\
\hline Sylvia curruca & & 8 & 6 & 9 & 4 & 3 & 30 \\
\hline Tringa totanus & & 0 & 0 & 0 & 0 & 1 & 1 \\
\hline Turdus philomelos & & 4 & 1 & 1 & 0 & 0 & 6 \\
\hline Upupa epops & & 0 & 1 & 0 & 1 & 1 & 3 \\
\hline Vanellus spinosus & & 2 & 0 & 0 & 3 & 0 & 5 \\
\hline Total & & 2990 & 2722 & 1613 & 2281 & 2931 & 12537 \\
\hline
\end{tabular}

General pattern of spring and autumn catching dynamics is presented in Figure 3. The spring migration was more prolonged and showed less differentiated wave-like character. This general picture of migration is composed of the species-specific migration patterns that are shown in Figure 4 (most numerous species). Figure 5 illustrates how differentiated were migration patterns in spring and autumn in different years, while Figure 6 shows the same for the autumn migration only (numbers of these species caught in spring were very low). 


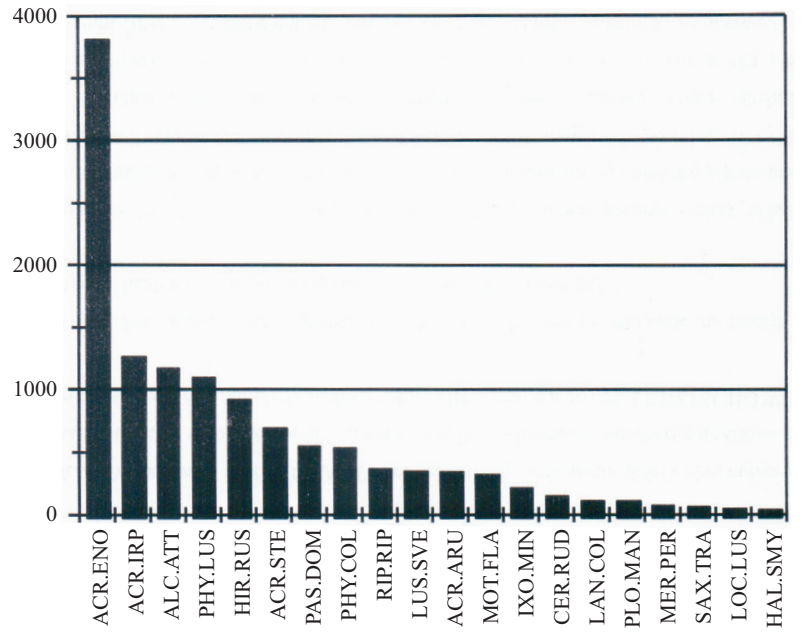

Fig. 2. Total number of individuals of twenty most numerous species caught at Burullus Ringing Station during all five seasons (tree autumns and two springs). For species codes see Table 1.
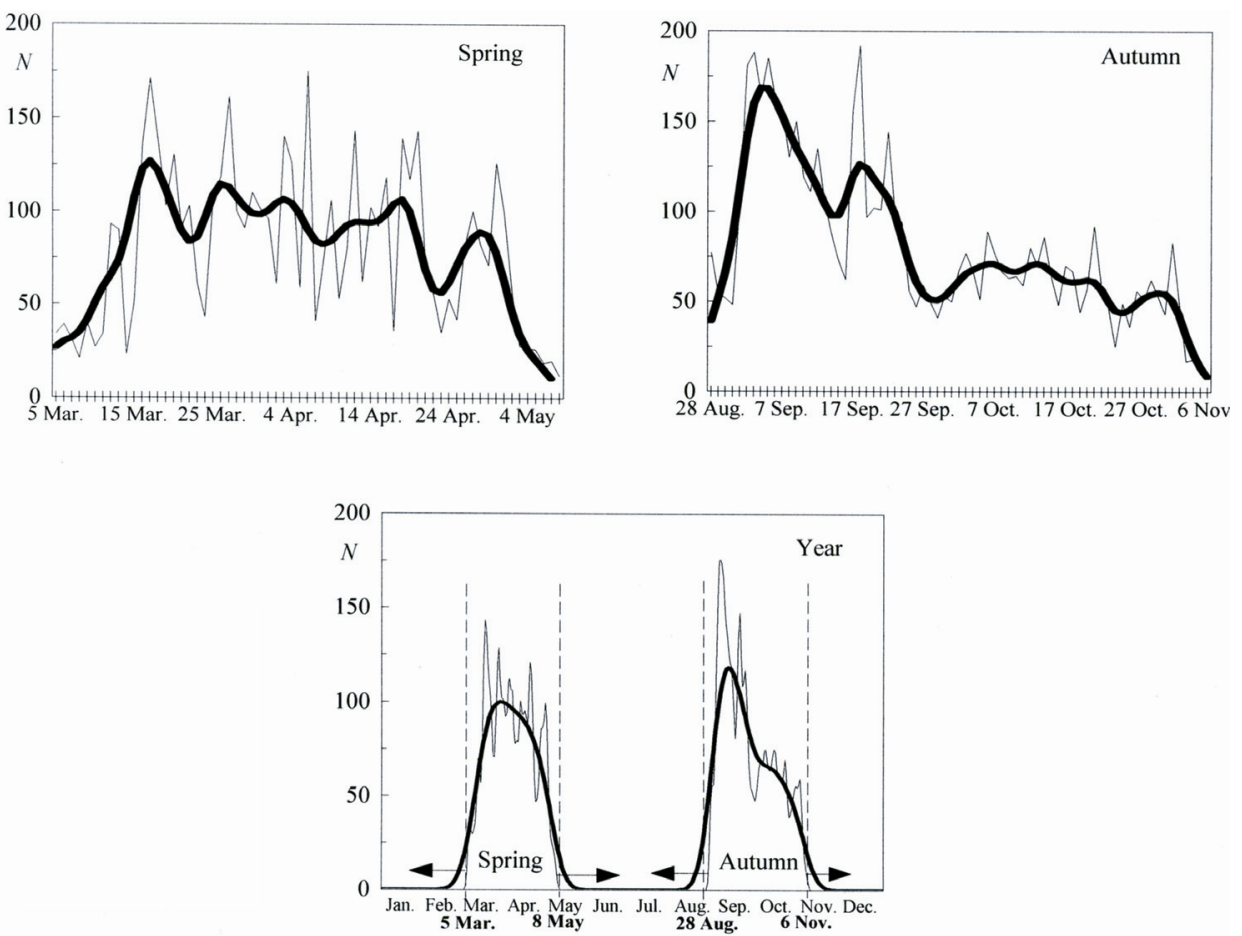

Fig. 3. Total dynamics of birds caught at Burullus station, during two spring (2006 and 2007) and two autumn seasons (2005 and 2006). Above - detailed seasonal results, below - simplified year-round pattern. Thin lines - daily results, thick lines - smoothed by moving average. Vertical intermittent line indicates borders of catching period. Horizontal arrows show potential direction of divergence between the catching period and the time of active migration over the study area. 


\section{DISCUSSION}

In 2005 a new ringing station Burullus started to work in the northern Egypt. Such vast stopover site as Burullus Wetlands seems to be crucial for numerous migrating bird species, especially due to location between two broad geographical barriers: the Mediterranean Sea and the Sahara Desert. Moreover, the neighbourhood of the Nile should attract many birds which use this river as a corridor for their migration.

So far it has been noted that Lake Burullus plays an important role particularly for migratory and resident waterbirds (Ramdani et al. 2001). The BirdLife International has identified this reservoir as an Important Bird Area (IBA) and it is also registered as a Ramsar site. Type of habitats surrounding Lake Burullus comprise mainly reedbeds, which clearly points that beside strict waterbirds such as ducks and wader species, there should also be some other species.

Generally one hundred twelve species of birds were recorded so far in Burullus Wetlands (Shaltout 2010). Taking into consideration that during our ringing activity over $66 \%$ of the total number of recorded bird species were caught, we can suspect that the list of noted species is underestimated for the area. Most probably further closer exploration would have a fair chance of new species records for this place.

Vast and quite monotonous reedbed habitat, which was used for placing nets during our ringing activity, strongly affected the composition of caught bird species. The Sedge Warbler was at the top of the list and the number of caught individuals was over three times higher than in the case of the Reed Warbler (Acrocephalus scirpaceus), which was on the second place among the most numerous species at the study site. These migratory species are both closely linked with the reedbeds, where nets were placed. The third place was taken by the Kingfisher, which is directly connected with fishponds, where these birds hunt intensely. There were even several cases when in the mist-nets there were found some fish, most probably the prey of Kingfishers accidentally released by ineffectively trapped birds.

Usually our ringing activity has been focused on migratory species, particularly long-distance migrants, however, at Burullus Ringing Station we also had an unusual opportunity to collect quite large biometrical data set from local resident species such as e.g. the Clamorous Reed Warbler (Acrocephalus stentoreus), White-throated Kingfisher (Halcyon smyrnensis) or the Pied Kingfisher (Ceryle rudis).

Both spring and autumn migration seasons at Burullus Wetlands seem to be far more extended in comparison to the periods of our ringing activity. Generally, for the medium-distance migrants, such as the Chiffchaff (Phylloscopus collybita) and the Bluethroat (Luscinia svecica), the ringing activity started later in spring (on 5 March) and ended earlier in autumn (on 6 November) than the passage of given species. The opposite situation took place during autumn seasons for the long-distance migrants, i.e. Sedge Warbler, Reed Warbler and Great Reed Warbler (Acrocephalus arundinaceus), when they had arrived at the ringing site probably a little earlier than on 28 August when the ringing activity began. 

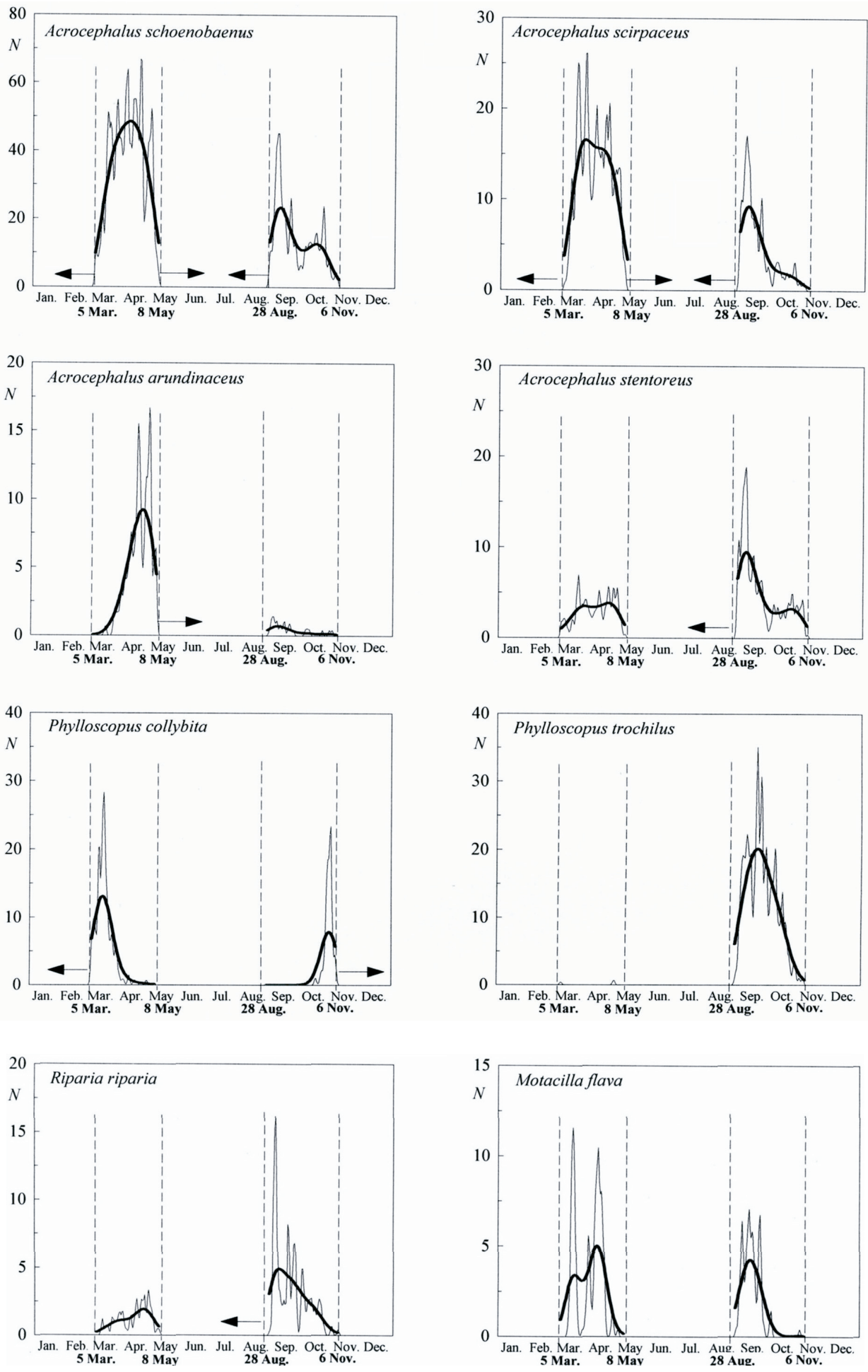

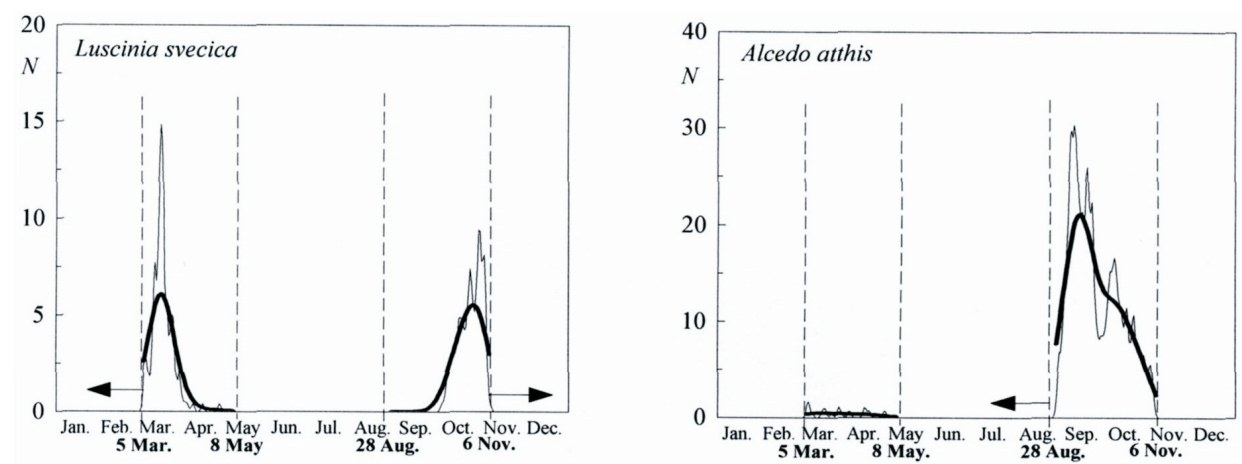

Fig. 4. Simplified yearly migration patterns of more numerous bird species at Burullus station. Explanations as for Figure 3 lower panel.

Differences between seasonal dynamics for separate years are difficult to interpret due to unfeasible assessment of cattle's influence. The cattle present in the area of catching caused direct damage to the mist-nets and also vast exploitation of the reed's leaves, which many of the birds feed on. The mentioned influence of the cattle was particularly high during autumn 2007, which is why this season was treated in a very limited way.

Despite only five analysed ringing seasons, clearly during spring migration the number of ringed birds, particularly from migratory species, was higher than during autumn season. If differences in the number of caught birds between autumn and spring seasons reliably reflected the intensity of migration, we could see that the general pattern of these differences is in agreement with results from other Middle East areas e.g. Israel (Morgan and Shirihai 1997, Yosef and Chernetsov 2004, Ożarowska et al. 2011). Such a regularity in changes of migration intensity between seasons detected for a number of soaring birds is connected with the using of different routes during spring and autumn migration (Leshem and Yom-Tov 1998). With regard to large differences in migratory strategies between small passerines and rather large soaring species, we cannot directly relate the mechanisms of these changes for both bird groups. We cannot also exclude that the geographical location of the study site affects somehow differences in the intensity of migration between spring and autumn seasons. Further closer research of the differences between migratory seasons supported by the analysis of fat amount for migrating birds seems to be essential.

\section{ACKNOWLEDGEMENTS}

We would like to acknowledge, in behalf of the SE European Bird Migration Network, the help that we received from the Burullus Protected Area staff during all our work at the station. Beside accommodation and transport facilities we were accompanied by the staff directly, especially by Mr Hani Mansour and Dr Elsayed Nafea. Dr Wed Ibrahim arranged this station and he was active during the fieldwork. In the work several Polish ringers participated. 
Acrocephalus schoenobaenus
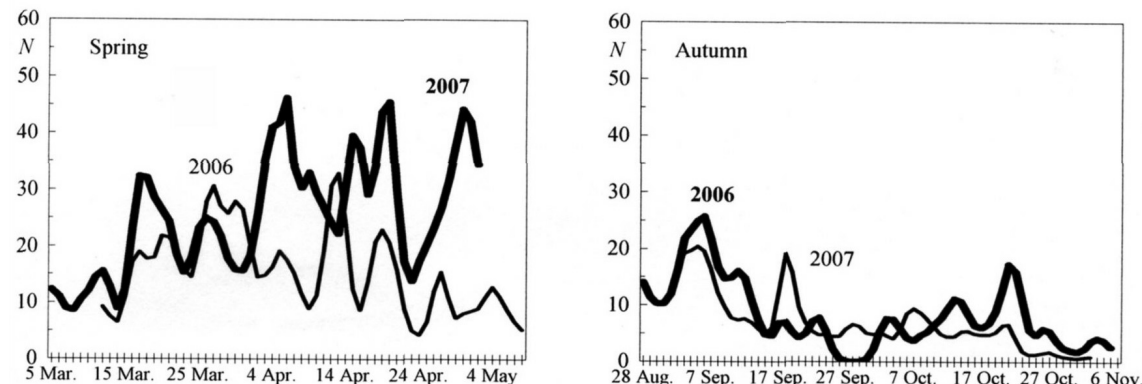

Acrocephalus scirpaceus
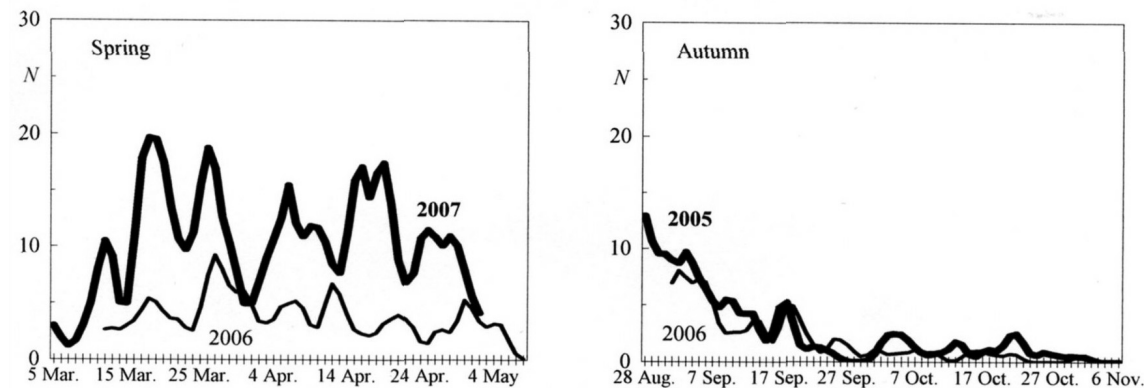

Phylloscopus collybita
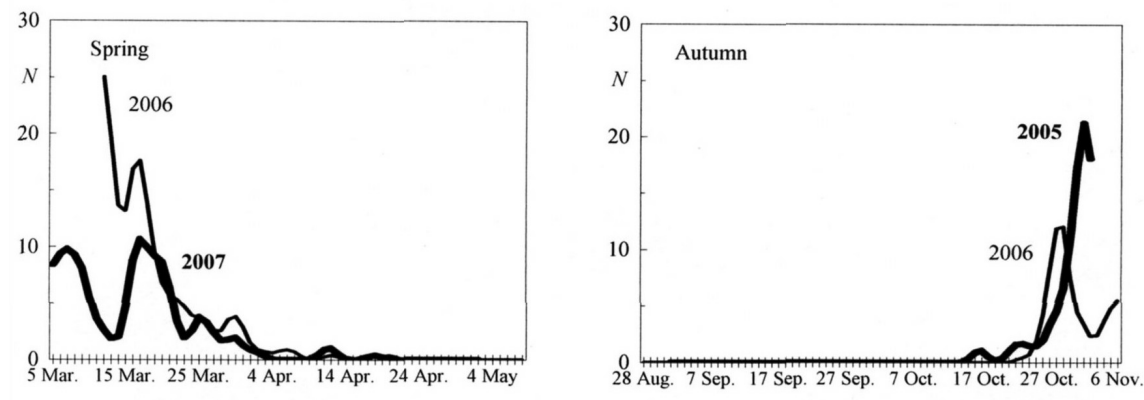

Luscinia svecica
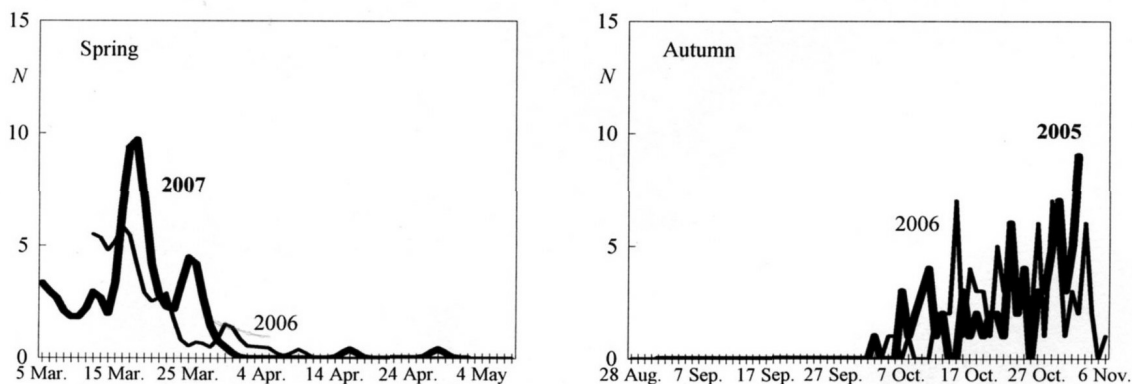

Fig. 5. Spring and autumn catching dynamics of more numerous bird species in different years 

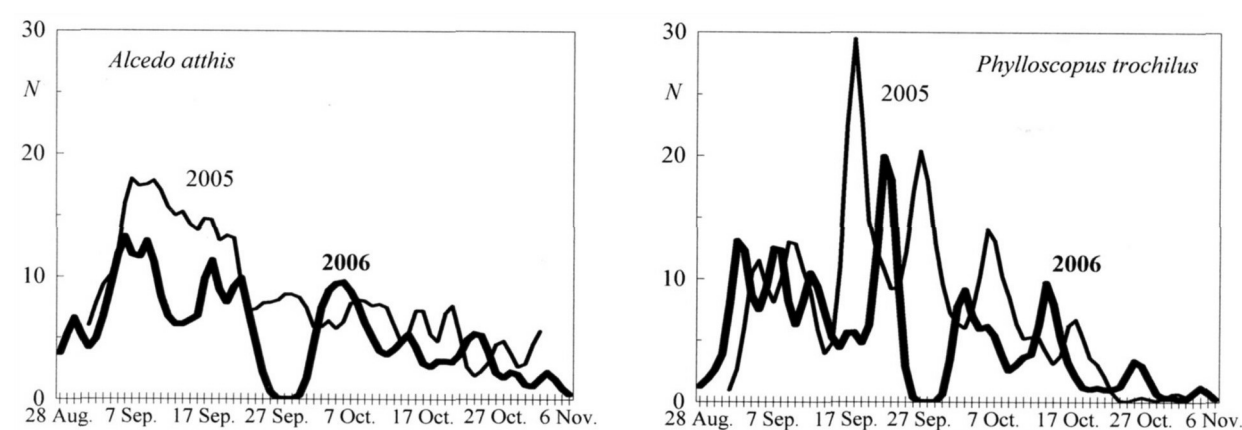

Fig. 6. Autumn catching dynamics of the Kingfisher and the Willow Warbler (in spring the numbers of caught individuals were very low)

\section{REFERENCES}

Busse P. 1984. Key to sexing and ageing of European passerines. Beitr. Naturk. Niedersachsens 37, Suppl.

Busse P. 1995. New technique of a field study of directional preferences of night passerine migrants. Ring 17, 1-2: 97-116.

Busse P. 2000. Bird station manual. SE European Bird Migration Network, Univ. of Gdańsk: 5-264.

Leshem Y., Yom-Tov Y. 1998. Routes of migrating soaring birds. Ibis 140: 41-52.

Morgan J.H, Shirihai H. 1997. Passerines and Passerine Migration in Eilat. IBCE Tech. Publ. 6, 1: $50 \mathrm{pp}$.

Ożarowska A., Stępniewska K., Ibrahim W.A.L. 2011. Autumn and spring migration of the Reed Warbler Acrocephalus scirpaceus in Egypt - some interesting aspects and questions. Ostrich 82: 49-56.

Ramdani M., Flower R.J., Elkhiat N., Kraïem M.M., Fathi A.A., Birks H.H., Patrick S.T. 2001. North African wetland lakes: characterization of nine sites included in the CASSARINA Project. Aquat. Ecol. 35: 281-302.

Shaltout K.H. 2010. Towards mainstreaming Lake Burullus biodiversity, North Egypt. Ass. Univ. Bull. Environ. Res. 13, 1: 71-87.

Svensson L. 1992. Identification guide to European Passerines. Stockholm.

Yosef R., Chernetsov N. 2004. Stopover ecology of migratory Sedge Warblers (Acrocephalus schoenobaenus) at Eilat, Israel. Ostrich 75: 52-56. 